\title{
Pengaruh Efektivitas Penggunaan, Kepercayaan dan Kualitas Sistem Informasi Akuntansi pada Kinerja Karyawan
}

\author{
Ni Luh Putu Dwi Gita Sari ${ }^{1}$ \\ I Made Pande Dwiana Putra ${ }^{2}$
}

\author{
${ }^{1,2}$ Fakultas Ekonomi dan Bisnis Universitas Udayana (Unud), Bali, Indonesia \\ e-mail: dwigitasari@gmail.com
}

\begin{abstract}
ABSTRAK
Perkembangan sistem informasi akuntansi telah merambah ke berbagai bidang kehidupan, salah satunya dimanfaatkan untuk kemajuan perusahaan. Keberlangsungan suatu perusahaan ditentukan oleh kinerja yang dimiliki oleh karyawan. Tujuan penelitian ini adalah untuk mengetahui pengaruh efektivitas penggunaan, kepercayaan dan kualitas sistem informasi akuntansi pada kinerja karyawan. Populasi dalam penelitian ini adalah karyawan bidang administrasi yang terdapat di PT Indonesia Power Unit Pembangkitan Bali. Jumlah sampel diperoleh dengan teknik sampling jenuh yaitu sebanyak 58 responden. Analisis data yang digunakan dalam penelitian ini adalah teknik analisis regresi linier berganda. Hasil penelitian ini menunjukkan bahwa efektivitas penggunaan, kepercayaan dan kualitas sistem informasi akuntansi berpengaruh positif pada kinerja karyawan.
\end{abstract}

Kata kunci: efektivitas penggunaan, kepercayaan, kualitas, kinerja karyawan

\begin{abstract}
The development accounting information system has penetrated into various fields of life, one of which is utilized for the progress of the company. The sustainability of a company is determined by the performance of the employee. The purpose of this study was to determine the effect of the effectiveness of the use, trust and quality of the accounting information system on employee performance. The population in this study were employees in the administration field at PT Indonesia Power Unit Pembangkitan Bali. The number of samples obtained by saturated sampling technique is as many as 58 respondents. Data analysis used in this study is a multiple linear regression analysis technique. The results of this study indicate that the effectiveness of the use, trust and quality of accounting information systems has a positive effect on employee performance.

Keywords: effectiveness of use, trust, quality, employee performance
\end{abstract}

\section{PENDAHULUAN}

Indonesia merupakan salah satu pengguna teknologi informasi terbesar di dunia.

Penggunaan teknologi informasi di era sekarang ini merupakan elemen penting dalam aktivitas perusahaan, dimana teknologi memberikan kesempatankesempatan untuk mendapatkan keunggulan kompetitif dan menawarkan kelengkapan untuk meningkatkan produktivitas serta keuntungan di masa 
Ni Luh Putu Dwi Gita Sari dan I Made Pande Dwiana Putra. Pengaruh...

mendatang. Kelton et al.(2010) menyatakan bahwa teknologi informasi berkembang dengan pesat, sehingga mempunyai dampak yang positif dan signifikan bagi perusahaan. Kebutuhan perusahaan akan informasi meningkat sejalan dengan perkembangan perusahaan. Semakin besar dan kompleks suatu perusahaan, maka semakin besar pula kebutuhan akan informasi. Informasi menjadi unsur penentu dalam pengambilan keputusan karena informasi digunakan untuk melakukan perencanaan, pengorganisasian, pengarahan dan pengendalian aktivitas perusahaan.

Perkembangan teknologi informasi mempunyai dampak yang sangat signifikan terhadap sistem informasi akuntansi dalam suatu organisasi bisnis, khususnya dalam pemrosesan data yang mengalami perubahan dari sistem manual digantikan dengan sistem komputer. Penggunaan sistem informasi akuntansi dalam perusahaan menuntut pemakai komputer meningkatkan kemampuannya dalam menggunakan komputer (Sari, 2009). Dengan semakin lihai pengguna atau pemakai komputer maka semakin efektif penerapan sistem informasi di suatu perusahaan.

Penggunaan teknologi informasi pada suatu perusahaan dalam menunjang sistem informasi membawa pengaruh terhadap kinerja karyawan. Kinerja karyawan yang baik merupakan salah satu faktor yang penting dalam meningkatkan produktivitas pada suatu perusahaan. Kinerja karyawan merupakan hasil atau tingkat keberhasilan seseorang secara keseluruhan selama periode tertentu di dalam melaksanakan tugas dibandingkan dengan berbagai kemungkinan, seperti standar hasil kerja, target atau sasaran atau kriteria yang 
telah ditentukan terlebih dahulu dan telah disepakati bersama. Christine (2009), mengemukakan kinerja karyawan dalam menjalankan fungsinya berhubungan dengan kepuasan kerja dan tingkat imbalan yang dipengaruhi oleh keterampilan, kemampuan dan sifat-sifat individu.

Sistem informasi dalam suatu perusahaan sangat mempengaruhi kinerja karyawan. Salah satu sistem informasi yang digunakan adalah sistem informasi akuntansi atau yang disingkat dengan SIA. SIA merupakan kumpulan sumber daya, seperti manusia dan peralatan yang dirancang untuk mengubah data keuangan dan data lainnya ke dalam informasi. informasi tersebut dikomunikasikan kepada para pembuatkeputusan (Bodnar dan Hopwood, 2000). Ratnaningsih (2013) menyatakan sistem informasi dapat digunakan untuk meningkatkan kecepatan, fleksibilitas, integrasi dan keakuratan informasi yang dihasilkan dengan demikian banyak pihak yang memanfaatkan sistem informasi akuntansi untuk mencapai keunggulan perusahaan.

Perkembangan teknologi yang sangat pesat untuk saat ini, sangat berpengaruh terhadap perkembangan SIA. Dengan menggunakan komputer informasi yang akan disajikan akan menjadi lebih tepat, cepat dan akurat. Pengaruh komputer sangat besar bagi perusahaan dalam hal sistem informasi dan pengambilan keputusan manajemen. SIA dirancang untuk mengatur arus dan pengelolaan data akuntansi dalam perusahaan sehingga data keuangan yang ada dalam perusahaan dapat bermanfaat dan dijadikan dasar pengambilan keputusan, baik bagi pihak manajemen maupun pihak lain di luar perusahaan. 
Ni Luh Putu Dwi Gita Sari dan I Made Pande Dwiana Putra. Pengaruh...

Meningkatnya perkembangan dunia dan kemajuan teknologi, membuat para pemakai informasi menginginkan kecepatan arus informasi dengan segera dalam rangka pengambilan keputusan. Sistem informasi baru yang diperlukan harus mampu menyajikan informasi yang diperlukan oleh manajemen dalam pengambilan keputusan dengan kriteria-kriteria tertentu yaitu: dapat dipercaya, akurat dan tepat. Oleh karena itu, apabila terdapat adanya keusangan dari sistem informasi (khususnya informasi akuntansi), maka harus segera diadakan modifikasi dan pengembangan sistem informasi. Secara umum dicapai melaluibeberapa tahap dimulai dengan perencanaan sistem, perancangan sistem dan diakhiri dengan pengoperasian sistem.

Irwansyah yang dikutip Jumaili (2005) mengemukakan bahwa penggunaan teknologi dalam sistem informasi perusahaan hendaknya mempertimbangkan pemakai. Penerapan SIA tidak akan terbebas dari permasalahan seperti para pemakai tidak mengerti cara mengoperasikan sistem sehingga kinerja sistem informasi yang dilakukan tidak akan maksimal sesuai dengan yang diharapkan dan tidak cocoknya sistem yang digunakan di suatu perusahaan. Goodhue dalam Jumaili (2005: 725) menyatakan bahwa jika evaluasi pemakai atas teknologi cocok dengan kemampuan dan tuntutan dalam tugas pemakai, maka akan memberikan dorongan pemakai memanfaatkan teknologi. Oleh sebab itu, evaluasi pemakai digunakan sebagai alat ukur keberhasilan pelaksanaan dan kualitas jasa sistem informasi yang dihubungkan dengan kecocokan tugas-tugas dengan teknologi. SIA yang modern dan canggih telah diimplementasikan dibanyak perusahaan dengan biaya yang besar, namun 
masalah yang timbul adalah penggunaan yang masih rendah terhadap SIA secara kontinyu. Rendahnya penggunaan SIA diidentifikasikan sebagai penyebab utama yang mendasari terjadinya productivity paradox yaitu investasi yang mahal di bidang sistem tetapi menghasilkan return yang rendah (Venkatesh dan Davis, 2000).

Enterprise Resource Planning (ERP) adalah suatu paket aplikasi perangkat lunak yang terintegrasi untuk digunakan secara luas di organisasi. ERP adalah salah satu perangkat Teknologi Informasi dan Komunikasi (TIK) yang handal, terdiri dari kumpulan modul-modul, seperti manufaktur, keuangan, Human Resources Departement (HRD), manajemen material, penjualan dan distribusi yang terhubung ke dalam database bersama (Falgenti dan Pahlevi, 2013). Hasil dari implementasi ERP tergantung pada bagaimana karyawan menggunakan sistem ERP (Pozzebon, 2000). Bagaimana menstimulasi karyawan untuk menggunakan sistem ERP secara efektif merupakan isu penting pada organisasi (Doll, Deng dan Scazzero, 2003). Menurut DeLone dan McLean (2003), penggunaan sistem bisa saja mandatory pada tahap pertama, setelah beberapa lama penggunaan sistem bisa saja menjadi voluntary. Selanjutnya tergantung dari penilaian manajemen tingkat atas untuk melanjutkan atau tidak melanjutkan penggunaan sistem apabila tidak menghasilkan keuntungan seperti yang diinginkan.

Banyak perusahaan sektor Usaha Besar (UB) di Indonesia yang sudah mengimplementasikan ERP. Beberapa peneliti telah mengevaluasi sistem ERP di perusahaan-perusahaan sektor UB tersebut, diantaranya Govindaraju dan 
Ni Luh Putu Dwi Gita Sari dan I Made Pande Dwiana Putra. Pengaruh...

Gondodirjo (2008) yang melakukan studi untuk mempelajari proses adopsi pengguna sistem ERP System Application and Product (ERP SAP) di PT. Telkom Indonesia. Minartiningtyas (2011) menemukan faktor-faktor yang mempengaruhi kesuksesan penerapan ERP SAP R/3 di PT. PLN (Persero) Distribusi Bali.Dari berbagai implementasi ERP di perusahaan-perusahaan, tidak terlepas dariadanya kegagalan dalam pengimplementasian yaitu tidak ada atau kurangnya dukungan dari pimpinan, proyek dianggap sebagai proyek dari satu departemen saja, tidak ada yang diserahi tugas untuk menjadi Person In Charge (PIC) dan untuk segala proses dan prosedur implementasi diserahkan hanya ke tim Information Technolgy (IT) saja.

Beberapa peneliti telah menggunakan model kesuksesan sistem informasi Delone dan McLean, diantaranya Hawari dan Heeks (2010) menggunakan model ini untuk mengetahui output dari implementasi ERP di sebuah perusahaan di Yordania. Penelitian ini menghasilkan beberapa faktor yang menyebabkan implementasi ERP gagal parsial, yaitu sistem yang tidak handal dengan waktu respon yang lambat dan tidak adanya dorongan kepada pengguna untuk berperan dan berpartisipasi dalam proses implementasi.

Penggunaan teknologi sistem informasi membawa pengaruh terhadap hampir semua aspek dalam pengelolaan bisnis, termasuk dalam pengelolaan bisnis kelistrikan. PT Indonesia Power merupakan salah satu anak Perusahaan PT PLN (Persero) yang menjadi perusahaan pembangkit tenaga listrik independen yang berorientasi bisnis murni. Unit Pembangkitan Bali merupakan salah satu unit pelaksana pengusahaan pembangkit yang berada di bawah PT Indonesia Power 
dan menyediakan tenaga listrik di Pulau Bali. Dengan identitas baru, Indonesia Power mendeklarasikan visi dan misi yang terintegrasi dengan rencana baru untuk menjadi perusahaan publik dan meningkatkan diri menjadi pembangkit kelas dunia. Untuk mendukung terealisasinya keinginan tersebut, Indonesia Power dan seluruh unit bisnisnya telah berbenah diri melalui implementasi ERP. ERP merupakan sistem informasi yang banyak digunakan oleh perusahaan-perusahaan di Indonesia salah satunya adalah PT Indonesia Power. ERP adalah sebuah aplikasi bisnis yang terintegrasi yang digunakan oleh perusahaan untuk kebutuhan pencatatan, penyimpanan, pengolahan dan pelaporan data dan informasi yang dihasilkan dari seluruh aktivitas bisnis seperti perencanaan, pengadaan, produksi, penjualan, pergudangan, akuntansi, pembayaran, dan lain-lain yang relevan.

Implementasi ERP di PT. Indonesia Power bukan merupakan hal yang baru, yakni dimulai pada tahun 2002 dengan Oracle E-Business Suite versi 11 yaitu Modul Financial pada tahun 2002 dan Modul Human Resources pada tahun 2008. Latar belakang adanya implementasi ERP di PT Indonesia Power disebabkan karena tuntutan kecepatan layanan, akurasi data dan kemudahan ketersediaan data untuk mendukung proses pengambilan keputusan manajemen. Selain itu, bertambahnya kompleksitas proses bisnis membutuhkan aplikasi bisnis yang terintegrasi dan mendukung konsep single entry.

ERP merupakan suatu sistem informasi yang berperan penting dalam menjalankan aktivitas bisnis perusahaan. Adapun kontribusi ERP dalam meningkatkan kinerja perusahaan di PT Indonesia Power UP Bali yaitu dapat meningkatkan transparansi dan efisiensi, mengintegrasikan data ke dalam 
Ni Luh Putu Dwi Gita Sari dan I Made Pande Dwiana Putra. Pengaruh...

informasi secara tepat waktu dalam proses pengambilan keputusan, menghindari ketidaksesuaian data atau tidak mengulang entri data, meningkatkan keunggulan kompetitif, dapat mempromosikan tata kelola perusahaan yang baikdan peningkatan profitabilitas. Adapun perbandingan sebelum dan setelah menggunakan sistem ERP di PT Indonesia Power UP Bali dapat dijelaskan pada Tabel 1.

Tabel 1.

\section{Perbandingan Penggunaan Sistem ERP di PT Indonesia Power Unit} Pembangkitan Bali

\begin{tabular}{lcc}
\hline & Sebelum Menggunakan Sistem ERP & Setelah Menggunakan Sistem ERP \\
\hline Proses & Proses disintegrasi & Proses terintegrasi \\
Data & Data redundansi & Data terpusat \\
Jam Kerja & Jam kerja tidak teratur & Efisiensi jam kerja \\
Kinerja & Sulit untuk mengukur & Transparan \\
\hline
\end{tabular}

Sumber: PT. Indonesia Power Unit Pembangkitan Bali, 2018

Teknologi informasi dapat memberi dampak-dampak terhadap perkembangan perekonomian sehingga persaingan pada setiap jenis usaha menjadi semakin ketat. Untuk menghadapi persaingan tersebut maka anggota atau karyawan dalam sebuah perusahaan harus menggunakan teknologi tersebut dengan baik agar teknologi informasi dapat dimanfaatkan secara efektif sehingga dapat memberikan kontribusi terhadap keberhasilan kinerja. Keberhasilan aplikasi sistem informasi pada suatu perusahaan dipengaruhi dari cara sistem itu dijalankan, tingkat kemudahan sistem itu bagi para pemakainya dan pemanfaatan teknologi yang digunakan.

Efektivitas dapat diartikan sebagai tingkatan pencapaian hasil yang diharapkan. Efektivitas kinerja sistem informasi akuntansi dapat dipengaruhi oleh beberapa faktor antara lain: keterlibatan pemakai pengguna dalam pengembangan sistem informasi, kemampuan teknik personal sistem informasi, ukuran 
organisasi, dukungan top manajemen, formalisasi pengembangan SIA, program pelatihan dan pendidikan pengguna SIA, keberadaan komite pengendali SIA dan lokasi departemen SIA (Luciana Spica dan Irmaya, 2007).

Kepercayaan terhadap teknologi sistem informasi dalam mengevaluasi kinerja karyawan diperlukan oleh manajemen untuk memastikan bahwa teknologi sistem informasi berbasis komputer yang digunakan dapat dipakai untuk mengendalikan kinerja bawahan. Kepercayaan adalah hal yang diperlukan oleh pemakai teknologi sistem informasi agar pemakai tersebut merasa bahwa teknologi sistem informasi yang diterapkan dapat meningkatkan kinerja individual dalam menjalankan kegiatan dalam perusahaan. Kepercayaan pemakai terhadap sistem informasi yang digunakan, informasi yang lebih tepat waktu, lebih akurat, dan lebih relevan, akan dapat meningkatkan kinerja bisnis, meningkatkan performa keputusan dan meningkatkan efisiensi.

Kualitas sistem berarti kombinasi hardware dan software dalam sistem informasi. Fokusnya adalah performa dari sistem, merujuk pada seberapa baik kemampuan perangkat keras, perangkat lunak, kebijakan, prosedur dari sistem informasi dapat menyediakan kebutuhan pengguna (DeLone dan McLean, 1992 dalam Kasandra, 2014). De Lone dan McLean (2010) menjelaskan bahwa sistem informasi yang berkualitas biasanya fleksibel, efisien, dapat diakses dan tepat waktu. Laudon (2008) menambahkan bahwa sistem informasi yang berkualitas memadukan efisiensi teknis dengan kepekaan terhadap kebutuhan organisasi dan manusia, menyebabkan kepuasan kerja yang lebih tinggi dan produktivitas. 
Ni Luh Putu Dwi Gita Sari dan I Made Pande Dwiana Putra. Pengaruh...

Penelitian yang dilakukan oleh Panggeso (2014) dengan judul efektivitas penggunaan dan kepercayaan atas SIA terhadap kinerja karyawan pada Bank SULSELBAR di Makassar. Hasil dari penelitian Panggeso menunjukkan bahwa efektivitas penggunaan dan kepercayaan atas SIA berpengaruh positif terhadap kinerja karyawan. Kasandra (2014) meneliti tentangpengaruh kualitas penerapan SIA, pemanfaatan dan kepercayaan teknologi informasi terhadap kinerja karyawan pada Bank Perkreditan Rakyat di Kabupaten Tabanan. Hasil yang diperoleh dari penelitian tersebut adalah kualitas penerapan SIA, pemanfaatan dan kepercayaan teknologi informasi berpengaruh positif dan signifikan terhadap kinerja karyawan. Pratama (2013) melakukan penelitian tentang pengaruh tingkat efektivitas SIA, keahlian pemakai komputer dan kenyamanan fisik terhadap kinerja karyawan pada PT. Bank Sinar Harapan Bali Denpasar yang hasilnya menunjukkan tingkat efektivitas SIA, keahlian pemakai komputer dan kenyamanan fisik berpengaruh positif terhadap kinerja karyawan.

Penelitian yang dilakukan oleh Dewantara (2014) di PDAM Kota Surakarta menyatakan efektivitas penggunaan dan kepercayaan sistem teknologi informasi berpengaruh positif terhadap kinerja individual. Baskoro (2015) juga melakukan penelitian tentang pengaruh tingkat keahlian pengguna, efektivitas penggunaan, pemanfaatan dan kepercayaan atas teknologi sistem informasi terhadap kinerja individual. Hasil yang diperoleh dari penelitian tersebut adalah pengaruh tingkat keahlian pengguna, efektivitas penggunaan, pemanfaatan dan kepercayaan atas teknologi sistem informasi berpengaruh positif terhadap kinerja individual. Dan 
Astuti (2014) melakukan penelitian tentang pengaruh efektivitas penerapan SIA, pemanfaatan dan kesesuaian tugas pada kinerja karyawan. Hasil dari penelitian Astuti menunjukkan bahwa pengaruh efektivitas penerapan SIA, pemanfaatan dan kesesuaian tugas dengan teknologi informasi memiliki pengaruh yang positif dan signifikan terhadap kinerja karyawan.

Teori yang digunakan untuk variabel efektivitas penggunaan SIA yaitu teori TPC yang menjelaskan bahwa keberhasilan teknologi sistem informasi yang diimplementasikan dalam suatu perusahaan dapat dinilai berdasarkan evaluasi pemakai. Model tersebut digunakan untuk menganalisa hubungan evaluasi pemakai dari kecocokan tugasdan teknologi terhadap kinerja. Jika teknologi informasi yang tersedia cocokdengan tugas yang harus diselesaikan dan kemampuan individu pemakai, makapemakai akan memanfaatkan teknologi sistem informasi dalam menjalankan tugas yang dibebankannya. Jadi teori TPC dalam kaitannya dengan efektivitas penggunaan SIA pada kinerja karyawan dapat menghasilkan sesuatu yang efektif. Teori ini mendukung penelitian tentang efektivitas penggunaan SIA yang dilakukan oleh Febri (2015) melalui teknik analisis regresi linier berganda. Hasil dalam penelitian ini menunjukkan bahwaefektivitas penggunaan teknologi sistem informasi akuntansi berpengaruh positif terhadap kinerja karyawan.

Penelitian dengan hasil serupa juga dilakukan oleh Sari (2009) dan Putri (2010) melalui model teknik analisis regresi berganda bahwa efektivitas penggunaan teknologi sistem informasi secara signifikan berpengaruh positif 
Ni Luh Putu Dwi Gita Sari dan I Made Pande Dwiana Putra. Pengaruh...

terhadap kinerja individual pada pasar swalayan di kota Denpasar.Berdasarkan teori dan hasil penelitian diatas, maka dapat ditarik hipotesis sebagai berikut:

$\mathrm{H}_{1}$ : Efektivitas penggunaan sistem informasi akuntansi berpengaruh positif pada kinerja karyawan.

Teori yang digunakan untuk variabel kepercayaan atas SIA yaitu teori TAM yang menjelaskan bahwa jika tidak ada kepercayaan pada sistem teknologi informasi yang digunakan maka pengguna tidak akan menggunakan sistem teknologi informasi tersebut. Hal ini didukung dengan adanya dua indikator dalam teori TAM yaitu persepsi kegunaan dan persepsi kemudahaan penggunaan. Persepsi kegunaan merupakan kepercayaan dalam proses pengambilan keputusan dimana sistem teknologi informasi memang berguna sehingga pemakai menggunakan sistem teknologi informasi tersebut. Sedangkan persepsi kemudahan penggunaan adalah kepercayaan dalam proses pengambilan keputusan dimana sistem teknologi informasi yang digunakan tidak dibutuhkan usaha yang besar pada saat pengoperasian. Kepercayaan terhadap sistem informasi yang baru mencerminkan sikap individu pemakai tentang keyakinan bahwa sistem yang baru ini lebih baik dari sistem sebelumnya. Kepercayaan ini bisa muncul karena kecepatan proses sistem yang baru dalam membatu pekerjaan, dan rasa keadilan dalam penerapan sistem baru ini bisa menilai kinerja individu dengan lebih baik. Jadi teori TPC dalam kaitannya dengan kepercayaan atas SIA pada kinerja karyawan dapat menghasilkan tingkat pencapaian kinerja yang lebih baik.

Teori TPC mendukung penelitian tentang kepercayaan atas SIA yang dilakukan oleh Sari (2009) yang meneliti tentang pengaruh efektivitas penggunaan dan kepercayaan terhadap teknologi sistem informasi akuntansi terhadap kinerja 
individual pada pasar swalayan di kota Denpasar. Hasil yang diperoleh adalah kepercayaan terhadap teknologi sistem informasi secara signifikan berpengaruh positif terhadap kinerja individual. Penelitian serupa juga dilakukan oleh Dewantara (2014) menggunakan teknik analisis linier berganda, bahwa hasil yang diperoleh mendukung hasil-hasil penelitian sebelumnya yaitu kepercayaan terhadap teknologi informasi akuntansi berpengaruh positif terhadap kinerja individual. Berdasarkan teori dan hasil penelitian diatas, maka dapat ditarik hipotesis sebagai berikut:

$\mathrm{H}_{2}$ : Kepercayaan atas sistem informasi akuntansi berpengaruh positif pada kinerja karyawan.

Teori yang digunakan untuk variabel kualitas SIA yaitu teori TAM yang menjelaskan bahwa kualitas SIA dinilai berdasarkan faktor-faktor yang menyebabkan munculnya sikap terbaik terhadap sistem dan kemudian dapat menerima serta menerapkan sistem tersebut. Dalam TAM terdapat dua indikator yaitu persepsi kegunaan dan persepsi kemudahan penggunaan. Persepsi kegunaan diartikan sebagai tingkatan dimana seseorang berfikir bahwa menggunakan suatu sistem akan meningkatkan kinerjanya. Sedangkan persepsi kemudahan penggunaan yaitu tingkatan seseorang mempercayai bahwa menggunakan teknologi hanya memerlukan sedikit usaha. Jadi teori TAM dalam kaitannya dengan kualitas SIA pada kinerja karyawan dapat menghasilkan sesuatu yang efektif dan efisien. Teori ini mendukung penelitian yang dilakukan oleh Wiryani (2009). Hasil dalam penelitian ini menunjukkan bahwa pengaruh pemakai berpengaruh positif terhadap kualitas sistem informasi akuntansi. Penelitian yang dilakukan oleh Putra (2016) juga memperoleh hasil yang sama 
Ni Luh Putu Dwi Gita Sari dan I Made Pande Dwiana Putra. Pengaruh...

bahwakualitas sistem informasi akuntansi berpengaruh positif terhadap kinerja karyawan pada PT PLN (Persero) Distribusi Bali.Berdasarkan teori dan hasil penelitian diatas, maka dapat ditarik hipotesis sebagai berikut:

$\mathrm{H}_{3}$ : Kualitas sistem informasi akuntansi berpengaruh positif pada kinerja karyawan

\section{METODE PENELITIAN}

Penelitian ini menggunakan pendekatan kuantitatif berbentuk asosiatif. Pendekatan asosiatif merupakan penelitian yang bertujuan untuk mengetahui hubungan atau pengaruh antara dua variabel atau lebih (Sugiyono, 2016). Pada penelitian ini variabel yang diuji yaitu pengaruh efektivitas penggunaan SIA, kepercayaan atas SIA, dan kualitas SIA pada kinerja karyawan. Model penelitian ini dapat dilihat pada Gambar 1.

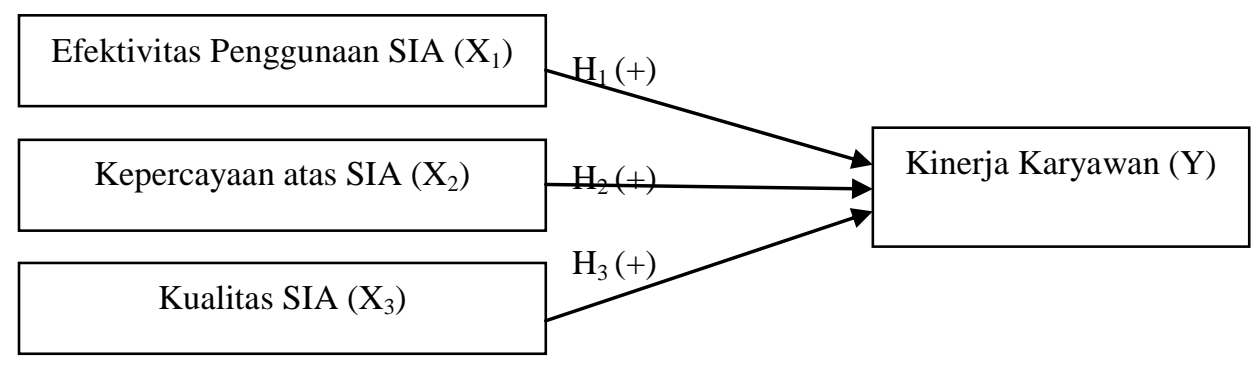

Sumber: Data diolah, 2018

\section{Gambar 1. Kerangka Konseptual}

Lokasi penelitian dilakukan di kantor PT. Indonesia Power Unit Pembangkitan Bali, beralamatkan di Jalan By Pass I Gusti Ngurah Rai No. 535 Pesanggaran, Denpasar. Yang melatarbelakangi lokasi ini dijadikan tempat penelitian adalah PT. Indonesia Power Unit Pembangkitan Bali merupakan salah satu pembangkit tenaga listrik yang berada di bawah PT Indonesia Power, menyediakan tenaga listrik untuk Pulau Bali. Dan pada PT Indonesia Power Unit 
Pembangkitan Bali, tentunya menggunakan sistem informasi akuntansi. Sistem informasi akuntansi yang baik dirancang dengan sedemikian rupa yang digunakan oleh karyawan pada perusahaan sehingga dapat memenuhi fungsinya, yaitu menghasilkan informasi akuntansi yang tepat waktu, relevan dan dipercaya bagi pihak yang berkepentingan. Sedangkan obyek dalam penelitian ini adalah kinerja karyawan yang dipengaruhi oleh efektivitas penggunaan, kepercayaan dan kualitas sistem informasi akuntansi.

Variabel bebas dalam penelitian ini adalah efektivitas penggunaan SIA $\left(\mathrm{X}_{1}\right)$, kepercayaan atas SIA $\left(\mathrm{X}_{2}\right)$ dan kualitas SIA $\left(\mathrm{X}_{3}\right)$. Sedangkan variabel terikat dalam penelitian ini adalah kinerja karyawan (Y). Skala pengukuran yang digunakan dalam penelitian ini menggunakan metode skala likert. Skala likert menggunakan empat skor dengan penilaian nilai skor 1 sampai 4 yaitu: 1 = sangat tidak setuju (STS), 2 = tidak setuju (TS), 3 = setuju $(\mathrm{S})$, dan $4=$ sangat setuju $(\mathrm{SS})$.

Jenis data yang digunakan dalam penelitian ini adalah data kuantitatif berupa data skor nilai dari jawaban kuesioner yang telah diisi oleh responden. Data kualitatif dalam penelitian ini berupa jumlah karyawan pada PT. Indonesia Power Unit Pembangkitan Bali, struktur organisasi dan tugas dari masing-masing bagian dalam perusahaan. Sedangkan sumber data yang digunakan dalam penelitian ini adalah data primer berupa hasil dari penyebaran kuesioner secara langsung kepada responden di PT. Indonesia Power Unit Pembangkitan Bali.

Populasi dalam penelitian ini adalah karyawan pada PT. Indonesia Power Unit Pembangkitan Bali yang menggunakan SIA yaitu sebanyak 58 orang. 
Ni Luh Putu Dwi Gita Sari dan I Made Pande Dwiana Putra. Pengaruh...

Metode penentuan sampel yang digunakan dalam penelitian ini adalah teknik sampling jenuh. Teknik sampling jenuh merupakan teknik penentuan sampel bila semua anggota populasi digunakan sebagai sampel Sugiyono (2016). Oleh karena itu peneliti mengambil jumlah sampel sama dengan jumlah populasi, yaitu sebanyak 58 responden.

Metode pengumpulan data yang digunakan dalam penelitian ini adalah kuesioner yaitu kuesioner akan langsung diantarkan kepada sasaran responden ke lokasi penelitian. Wawancara yaitu metode tanya jawab atau pertemuan dua orang untuk bertukar informasi dan ide dalam suatu topik tertentu yang ingin digunakan apabila peneliti ingin mengetahui hal-hal yang lebih mendalam (Sugiyono, 2016).

Teknik analisis data yang digunakan dalam penelitian ini adalah teknik analisis regresi linier berganda. Sebelum melakukan pengujian regresi, terdapat beberapa asumsi yang harus dipenuhi agar data yang akan dimasukkan dalam model regresi telah memenuhi ketentuan dan syarat dalam regresi. Uji asumsi klasik dalam penelitian ini mencakup uji normalitas, multikolinearitas, dan heteroskedastisitas. Model regresi linier berganda dirumuskan sebagai berikut.

$$
\mathrm{Y}=\alpha+\beta_{1} \mathrm{X}_{1}+\beta_{2} \mathrm{X}_{2}+\beta_{3} \mathrm{X}_{3}+\mathrm{e}
$$

Keterangan:

$\mathrm{Y} \quad=$ Kinerja karyawan

$\alpha=$ Konstanta

$\beta_{1 \ldots} \beta_{3}=$ Koefisien regresi

$\mathrm{X}_{1}=$ Efektivitas penggunaan

$\mathrm{X}_{2}=$ Kepercayaan

$\mathrm{X}_{3}=$ Kualitas

$\mathrm{e} \quad=$ Variabel pengganggu 


\section{HASIL DAN PEMBAHASAN}

Karakteristik responden penelitian ini merupakan profil dari 42 responden yang berpartisipasi dalam pengisian kuesioner. Karakteristik responden penelitian meliputi jenis kelamin, jenjang pendidikan dan lama bekerja, karakteristik responden dapat dilihat pada Tabel 2.

Tabel 2.

Karakteristik Responden

\begin{tabular}{|c|c|c|c|}
\hline \multirow{2}{*}{ NO } & \multirow{2}{*}{ Karakteristik Responden } & \multicolumn{2}{|c|}{ Jumlah } \\
\hline & & Orang & Persentase $(\%)$ \\
\hline \multirow[t]{4}{*}{1} & Jenis Kelamin & & \\
\hline & Laki-Laki & 22 & 52,38 \\
\hline & Perempuan & 20 & 47,62 \\
\hline & Total & 42 & 100 \\
\hline \multirow[t]{7}{*}{2} & Jenjang Pendidikan & & \\
\hline & D3 & 12 & 28,57 \\
\hline & $\mathrm{S} 1$ & 19 & 45,24 \\
\hline & $\mathrm{S} 2$ & 0 & 0,00 \\
\hline & $\mathrm{S} 3$ & 0 & 0,00 \\
\hline & Lainnya & 11 & 26,19 \\
\hline & Total & 42 & 100 \\
\hline \multirow[t]{7}{*}{3} & Lama Bekerja & & \\
\hline & $<5$ Tahun & 13 & 30,95 \\
\hline & 5-9 Tahun & 7 & 16,67 \\
\hline & 10 - 14 Tahun & 7 & 16,67 \\
\hline & 15 - 19 Tahun & 4 & 9,52 \\
\hline & $>20$ Tahun & 11 & 26,19 \\
\hline & Total & 42 & 100 \\
\hline
\end{tabular}

Sumber : Data yang diolah, 2018

Tabel 2. menunjukkan proporsi karyawan laki-laki dan perempuan berdasarkan jenis kelamin. Pada Tabel 4.2 dapat diketahui jumlah karyawan lakilaki sebanyak 22 orang responden $(52,83 \%)$ dan karyawan perempuan sebanyak 20 orang responden $(47,62 \%)$. Berdasarkan jenjang pendidikan yang dimiliki responden. Pada Tabel 2. responden yang memiliki tingkat pendidikan D3 sebanyak 12 orang $(28,57 \%)$, S1 sebanyak 19 orang $(45,24 \%)$ dan lain-lain 
Ni Luh Putu Dwi Gita Sari dan I Made Pande Dwiana Putra. Pengaruh...

sebanyak 11 orang $(26,19 \%)$. Berdasarkan lama bekerja menunjukkan responden yang lama bekerja sebagai karyawan kurang dari lima tahun sebanyak 13 orang (30,95\%). Responden yang lama bekerja antara 5 sampai 9 tahun sebanyak 7 orang (16,67\%). Responden yang lama bekerja antara 10 sampai 14 tahun sebanyak 7 orang (16,67\%). Responden yang lama bekerja antara 15 sampai 19 tahun sebanyak 4 orang $(9,52 \%)$. Responden yang lama bekerja lebih dari 20 tahun sebanyak 11 orang $(26,19 \%)$.

Suatu instrumen yang valid ditunjukkan dengan $\mathrm{r}$ Pearson Correlation $\geq$ 0,30. Pada Tabel 3. menunjukkan bahwa seluruh variabel memiliki nilai koefisien korelasi dengan skor total seluruh item pernyataan lebih besar dari 0,30 . Hal ini menunjukkan butir-butir pernyataan dalam instrumen penelitian tersebut valid.

Hasil uji validitas instrumen penelitian yang disajikan pada tabel dibawah menunjukkan bahwa semua instrument penelitian yang digunakan untuk mengukur variabel penelitian, yaitu: kinerja karyawan, efektifitas penggunaan SIA, kepercayaan atas SIA, dan kualitas SIA memiliki nilai koefisien korelasi di atas 0,30 sehingga seluruh indikator yang digunakan dinyatakan valid.

Tabel 3.

Hasil Uji Validitas

\begin{tabular}{cccc}
\hline Variabel & $\begin{array}{c}\text { Item } \\
\text { Pernyataan }\end{array}$ & Nilai Korelasi & Keterangan \\
\hline Kinerja Karyawan $(\mathrm{Y})$ & $\mathrm{Y}_{1}$ & 0,888 & Valid \\
& $\mathrm{Y}_{2}$ & 0,895 & Valid \\
& $\mathrm{Y}_{3}$ & 0,846 & Valid \\
& $\mathrm{Y}_{4}$ & 0,853 & Valid \\
& $\mathrm{Y}_{5}$ & 0,898 & Valid \\
\hline Efektivitas Penggunaan & $\mathrm{X}_{1.1}$ & 0,860 & Valid \\
SIA (X $\left.\mathrm{X}_{1}\right)$ & $\mathrm{X}_{1.2}$ & 0,797 & Valid \\
& $\mathrm{X}_{1.3}$ & 0,840 & Valid \\
& $\mathrm{X}_{1.4}$ & 0,884 & Valid \\
\hline
\end{tabular}




\begin{tabular}{cccc}
\hline & $\mathrm{X}_{1.5}$ & 0,909 & Valid \\
& $\mathrm{X}_{1.6}$ & 0,845 & Valid \\
& $\mathrm{X}_{1.7}$ & 0,865 & Valid \\
\hline Kepercayaan atas SIA & $\mathrm{X}_{2.1}$ & 0,892 & Valid \\
$\left(\mathrm{X}_{2}\right)$ & $\mathrm{X}_{2.2}$ & 0,848 & Valid \\
& $\mathrm{X}_{2.3}$ & 0,873 & Valid \\
& $\mathrm{X}_{2.4}$ & 0,811 & Valid \\
& $\mathrm{X}_{2.5}$ & 0,886 & Valid \\
& $\mathrm{X}_{2.6}$ & 0,867 & Valid \\
\hline Kualitas SIA $\left(\mathrm{X}_{3}\right)$ & $\mathrm{X}_{3.1}$ & 0,930 & Valid \\
& $\mathrm{X}_{3.2}$ & 0,873 & Valid \\
& $\mathrm{X}_{3.3}$ & 0,880 & Valid \\
& $\mathrm{X}_{3.4}$ & 0,923 & Valid \\
& $\mathrm{X}_{3.5}$ & 0,904 & Valid \\
\hline
\end{tabular}

Sumber : Data diolah, 2018

Uji reliabilitas dilakukan untuk menunjukkan sejauh mana suatu pengukuran kembali terhadap gejala yang sama. Suatu instrument dikatakan reliabel apabila instrument tersebut telah beberapa kali digunakan untuk mengukur objek yang sama dan menghasilkan data atau jawaban yang sama dari waktu ke waktu. Secara umum suatu instrumen dikatakan bagus jika memiliki koefisien Cronbach's Alpha > 0,60 maka kuesioner penelitian tersebut dinyatakan reliabel. Hasil uji reliabilitas dapat dilihat pada Tabel 4.

Hasil uji reliabilitas yang ditampilkan dalam Tabel 4. menunjukkan bahwa setiap variabel memiliki nilai koefisien Alpha Cronbach lebih besar dari 0,60 $(>0,60)$. Semua variabel dalam penelitian ini adalah reliabel dan pernyataan dalam kuesioner layak digunakan sebagai alat ukur.

Tabel 4.

Hasil Uji Reliabilitas

\begin{tabular}{clcc}
\hline No & \multicolumn{1}{c}{ Instrumen Variabel } & Cronbach's Alpha & Kriteria \\
\hline 1 & Kinerja Karyawan $(Y)$ & 0,924 & Reliabel \\
2 & Efektivitas Penggunaan SIA $\left(\mathrm{X}_{1}\right)$ & 0,939 & Reliabel \\
3 & Kepercayaan atas SIA $\left(\mathrm{X}_{2}\right)$ & 0,931 & Reliabel \\
4 & Kualitas SIA $\left(\mathrm{X}_{3}\right)$ & 0,943 & Reliabel \\
\hline
\end{tabular}

Sumber: Data diolah, 2018 
Ni Luh Putu Dwi Gita Sari dan I Made Pande Dwiana Putra. Pengaruh...

Uji normalitas menggunakan uji Kolmogorov-Smirnov, dengan uji ini dapat diketahui data yang digunakan berdistribusi normal atau tidak. Apabila Sign t hitung > 0.05, maka data tersebut berdistribusi normal dan begitu juga sebaliknya (Santoso, 2001).

Tabel 5. Hasil Uji Normalitas

\begin{tabular}{llr}
\hline & & Unstandardized Residual \\
\hline $\mathrm{N}$ & & 42 \\
Normal Parameters & Mean & 0,0000000 \\
& Std. Deviation & 1,85465556 \\
Most Extreme Differences & Absolute & 0,127 \\
& Positive & 0,127 \\
& Negative & $-0,109$ \\
Test Statistic & & 0,127 \\
Asymp. Sig. (2-tailed) & & 0,085 \\
\hline Sumber: Data diolah, 2018 & &
\end{tabular}

Berdasarkan hasil uji normalitas yang ditampilkan pada Tabel 5. diperoleh nilai signifikansi sebesar 0,085 dimana nilai signifikansi tersebut lebih besar dari 0,05, maka dapat disimpulkan bahwa data terdistribusi secara normal.

Uji multikolinieritas digunakan untuk mengetahui apakah antara variabel bebas terjadi multikolinieritas atau tidak. Uji yang digunakan yaitu dengan melihat nilai VIF (Varian Inflation Factor) dan Tolerance pada proses regresi biasa, jika keduanya mendekati 1 atau besaran VIF kurang dari 10 maka model tidak terkena multikolinieritas. Berdasasrkan hasil pengujian multikolinearitas dapat diperoleh hasil sebagai berikut.

Tabel 6.

Hasil Uji Multikolinearitas

\begin{tabular}{lcc}
\hline \multirow{2}{*}{ Variabel } & \multicolumn{2}{c}{ CollinearityStatistics } \\
\cline { 2 - 3 } & Tolerance & VIF \\
\hline Efektivitas penggunaan SIA $\left(\mathrm{X}_{1}\right)$ & 0,735 & 1,360 \\
Kepercayaan atas SIA $\left.\mathrm{X}_{2}\right)$ & 0,761 & 1,314 \\
Kualitas SIA $\left(\mathrm{X}_{3}\right)$ & 0,789 & 1,268 \\
\hline Sumber: Data diolah, 2018 & \multicolumn{2}{c}{}
\end{tabular}


Hasil pengujian pada Tabel 6. menunjukkan bahwa nilai tolerance pada masing-masing variabel lebih besar dari $10 \%(0,1)$, demikian pula dengan nilai VIF masing-masing variabel yang lebih kecil dari 10. Dengan demikian dapat disimpulkan antara variabel bebas dalam penelitian ini tidak terjadi multikolinearitas.

Uji Heterokedastisitas dilakukan untuk menguji apakah dalam model regresi terjadi ketidaksamaan varian dari residu satu pengamatan ke pengamatan lain. Model regresi yang baik adalah model homokedastisitas atau tidak terjadi heterokedastisitas. Apabila model suatu regresi mengandung gejala heterokedastisitas, maka hasil yang diberikan akan menyimpang. Untuk mengetahui apakah sebuah regresi memiliki indikasi heterokedastisitas, maka masalah tersebut bisa dideteksi dengan menggunakan uji Glejser Test. Jika probabilitas signifikansinya di atas 0,05 maka dapat dikatakan bahwa pada model regresi tidak mengandung masalah heterokedastisitas . Hasil uji heterokedastisitas dapat dilihat pada Tabel 7.

Tabel 7.

Hasil Uji Heteroskedastisitas

\begin{tabular}{lcl}
\hline \multicolumn{1}{c}{ Variabel } & Sig. & \multicolumn{1}{c}{ Keterangan } \\
\hline Efektivitas penggunaan SIA $\left(\mathrm{X}_{1}\right)$ & 0,348 & Bebas heteroskedastisitas \\
Kepercayaan atas SIA $\left(\mathrm{X}_{2}\right)$ & 0,140 & Bebas heteroskedastisitas \\
Kualitas SIA $\left(\mathrm{X}_{3}\right)$ & 0,247 & Bebas heteroskedastisitas \\
\hline Sumber: Data diolah, 2018. & &
\end{tabular}


Ni Luh Putu Dwi Gita Sari dan I Made Pande Dwiana Putra. Pengaruh...

Tabel 7. menunjukkan bahwa seluruh variabel memiliki nilai signifikan lebih besar dari 0,05 sehingga model regresi pada penelitian ini tidak mengandung gejala heteroskedastisitas.

Analisis linier berganda ini digunakan untuk mengetahui besarnya pengaruh efektivitas penggunan, kepercayaan dan kualitas SIA pada kinerja karyawan PT Indonesia Power Unit Pembangkitan Bali. Hasil perhitungan analisis linier berganda yang dijabarkan dengan menggunakan program SPPS versi 22.0. Hasil analisis regresi linier berganda disajikan pada Tabel 8.

Tabel 8.

Hasil Analisis Regresi Linier Berganda

\begin{tabular}{|c|c|c|c|c|c|c|}
\hline \multirow[b]{2}{*}{ Model } & & \multicolumn{2}{|c|}{$\begin{array}{c}\text { Unstandardized } \\
\text { Coefficients }\end{array}$} & \multirow{2}{*}{$\begin{array}{c}\text { Standardize } \\
\text { Coefficient } \\
\text { Beta }\end{array}$} & \multirow[b]{2}{*}{$\mathrm{t}$} & \multirow[b]{2}{*}{ Sig. } \\
\hline & & $\mathrm{B}$ & Error & & & \\
\hline \multicolumn{2}{|c|}{$\begin{array}{l}\text { (Constant) } \\
\text { (C) }\end{array}$} & $-2,609$ & 1,325 & & $-1,969$ & 0,056 \\
\hline \multicolumn{2}{|c|}{ Efektivitas Penggunaan SIA } & 0,400 & 0,058 & 0,548 & 6,847 & 0,000 \\
\hline \multicolumn{2}{|c|}{ Kepercayaan atas SIA } & 0,279 & 0,067 & 0,330 & 4,192 & 0,000 \\
\hline \multicolumn{2}{|c|}{ Kualitas SIA } & 0,255 & 0,075 & 0,263 & 3,397 & 0,002 \\
\hline$R$-Square & $: 0,821$ & & & & & \\
\hline F Hitung & : 57,995 & & & & & \\
\hline Sig F & $: 0,000^{\mathrm{b}}$ & & & & & \\
\hline
\end{tabular}

Berdasarkan Tabel 8. di atas, dapat disusun persamaan regresi sebagai berikut:

$$
Y=-2,609+0,400 X_{1}+0,279 X_{2}+0,255 X_{3}+e
$$

Berdasarkan persamaan tersebut nilai konstanta sebesar -2,609 menyatakan bahwa apabila variabel efektivitas penggunaan SIA $\left(\mathrm{X}_{1}\right)$, kepercayaan atas SIA $\left(\mathrm{X}_{2}\right)$ dan kualitas SIA $\left(\mathrm{X}_{3}\right)$ sama dengan nol, maka tidak terdapat perubahan kinerja karyawan.

Berdasarkan Tabel 8. menunjukkan bahwa koefisien determinasi yaitu nilai adjusted $R^{2}$ adalah 0,821 . Hal ini berarti variansi variabel independen yaitu 
efektivitas penggunaan SIA, kepercayaan atas SIA dan kualitas SIA, dapat menerangkan variansi variabel dependen yaitu kinerja karyawan sebesar 82,1\%, sisanya sebesar $17,9 \%$ diterangkan oleh variabel lain yang tidak dimasukkan dalam model regresi pada penelitian ini.

Uji koefisien regresi secara simultan atau uji-F dilakukan dengan tujuan untuk mengetahui apakah semua variabel independen efektivitas penggunaan SIA, kepercayaan atas SIA dan kualitas SIA mempunyai pengaruh bersama-sama secara signifikan atau tidak terhadap variabel dependen kinerja karyawan. Berdasarkan hasil uji regresi yang telah dilakukan maka didapat hasil uji $\mathrm{F}$ menunjukkan bahwa nilai $\mathrm{F}$ hitung adalah sebesar 57,995 dengan nilai signifikansi P value 0,000 yang lebih kecil dari $\alpha=0,05$. Hal ini berarti model yang digunakan pada penelitian ini adalah layak. Efektivitas penggunaan SIA $\left(\mathrm{X}_{1}\right)$, kepercayaan atas SIA $\left(\mathrm{X}_{2}\right)$ dan kualitas SIA $\left(\mathrm{X}_{3}\right)$ secara serempak berpengaruh pada kinerja karyawan (Y).

Uji $\mathrm{t}$ dalam penelitian ini bertujuan untuk menguji apakah masing-masing variabel bebas $(\mathrm{X})$ yang digunakan dalam model regresi memiliki pengaruh pada variabel terikat $(\mathrm{Y})$. Apabila nilai signifikansinya > 0,05 maka hipotesis ditolak (koefisien regresi tidak signifikan), dan apabila nilai signifikansi $\leq 0,05$ maka hipotesis diterima (koefisien regresi signifikan).

Berdasarkan hasil pengujian dalam penelitian ini didapatkan hasil bahwa efektivitas penggunaan SIA mempunyai pengaruh positif pada kinerja karyawan. Hal tersebut diketahui dari tingkat $P$-value $\mathrm{X}_{1}$ (efektivitas penggunaan SIA) sebesar $0,000<0,05$. Hasil pengujian tersebut menunjukkan bahwa hipotesis 
Ni Luh Putu Dwi Gita Sari dan I Made Pande Dwiana Putra. Pengaruh...

pertama $\left(\mathrm{H}_{1}\right)$ efektivitas penggunaan SIA mempunyai pengaruh yang positif pada kinerja karyawan diterima. Hal ini berarti bahwa semakin tinggi tingkat efektivitas penggunaan SIA menyebabkan peningkatan kinerja karyawan pada PT Indonesia Power Unit Pembangkitan Bali.

Hasil penelitian ini sejalan dengan penelitian sebelumnya yang dilakukan oleh Sari (2009) dan Putri (2010) melalui model teknik analisis regresi berganda bahwa efektivitas penggunaan teknologi sistem informasi secara signifikan berpengaruh positif terhadap kinerja individual pada pasar swalayan di kota Denpasar. Selain penelitian tersebut, penelitian ini juga sejalan dengan penelitian yang dilakukan oleh Febri (2015) melalui teknik analisis regresi linier berganda bahwa efektivitas penggunaan teknologi sistem informasi akuntansi berpengaruh positif terhadap kinerja karyawan.

Berdasarkan hasil pengujian dalam penelitian ini didapatkan hasil bahwa kepercayaan atas SIA mempunyai pengaruh positif pada kinerja karyawan. Hal tersebut diketahui dari tingkat $P$-value $\mathrm{X}_{2}$ (kepercayaan atas SIA) sebesar $0,000<$ 0,05. Hasil pengujian tersebut menunjukkan bahwa hipotesis kedua $\left(\mathrm{H}_{2}\right)$ kepercayaan atas SIA mempunyai pengaruh positif pada kinerja karyawan diterima. Hal ini berarti bahwa semakin tinggi tingkat kepercayaan SIA menyebabkan peningkatan kinerja karyawan pada PT Indonesia Power Unit Pembangkitan Bali.

Hasil penelitian ini sejalan dengan penelitian sebelumnya yang dilakukan olehSari (2009) dan Dewantara (2014) yang menunjukkan bahwa kepercayaan terhadap teknologi SIA berpengaruh positif terhadap kinerja individual. Selain 
ketiga penelitian tersebut, penelitian ini juga sejalan dengan penelitian yang dilakukan Marlinawati (2013) dan Baskoro (2015) menyatakan bahwa kepercayaan atas SIA berpengaruh positif terhadap kinerja karyawan.

Sari (2009) menyatakan kepercayaan terhadap teknologi informasi akan mengarahkan individu untuk mencapai kinerja yang lebih baik. Dalam penelitian ini kepercayaan adalah hal yang diperlukan individu pemakai teknologi informasi agar mereka merasa bahwa teknologi dapat meningkatkan kinerja individu dalam menjalankan kegiatan perusahaan. Karyawan yang memiliki kepercayaan terhadap penerapan teknologi SIA akan berusaha untuk menggunakan teknologi informasi demi mendukung kinerjanya.

Berdasarkan hasil pengujian dalam penelitian ini didapatkan hasil bahwa kualitas SIA mempunyai pengaruh positif pada kinerja karyawan. Hal tersebut diketahui dari tingkat $P$-value $\mathrm{X}_{3}$ (kualitas $\mathrm{SIA}$ ) sebesar $0,002<0,05$. Hasil pengujian tersebut menunjukkan bahwa hipotesis ketiga $\left(\mathrm{H}_{3}\right)$ yaitu kualitas SIA mempunyai pengaruh positif pada kinerja karyawan diterima. Hal ini menunjukkan bahwa semakin tinggi tingkat kualitas SIA menyebabkan peningkatan kinerja karyawan pada PT Indonesia Power Unit Pembangkitan Bali. Hasil penelitian ini sejalan dengan penelitian sebelumnya yang dilakukan oleh Rahmi (2013) dan Putra (2016) menunjukkan bahwa kualitas SIA berpengaruh positif terhadap kinerja karyawan dan kinerja perusahaan. 
Ni Luh Putu Dwi Gita Sari dan I Made Pande Dwiana Putra. Pengaruh...

\section{SIMPULAN}

Berdasarkan pembahasan hasil penelitian di atas, dapat disimpulkan bahwa Efektivitas penggunaan sistem informasi akuntansi, kepercayaan atas sistem informasi akuntansi, dan kualitas sistem informasi akuntansi berpengaruh positif pada kinerja karyawan PT Indonesia Power Unit Pembangkitan Bali. Sedangkan saran yang dapat diberikan adalah perusahaan harus selalu konsisten untuk meningkatkan kinerja karyawan. Perusahaan diharapkan dapat menjaga keamanan sistem informasi agar tidak mudah mengalami gangguang-gangguan baik dari faktor internal maupun eksternal. Perusahaan juga harus rutin mengevaluasi dan memperbaharui sistem informasi akuntansi yang digunakan untuk meningkatkan perkembangan PT Indonesia Power Unit Pembangkitan Bali dari segi kualitas dan kinerja karyawannya sehingga selalu dipercaya oleh masyarakat sebagai perusahaan yang baik.

\section{REFERENSI}

Astuti, N. M. M. (2014). Pengaruh Efektivitas Penerapan Sistem Informasi Akuntansi, Pemanfaatan dan Kesesuaian Tugas dengan Teknologi Informasi terhadap Kinerja Karyawan pada Koperasi Simpan Pinjam di Kabupaten Gianyar. E-Jurnal Akuntansi, Universitas Udayana, 9(2).

Baskoro, B. A. (2015). Pengaruh Keahlian Pengguna, Efektivitas Penggunaan, Pemanfaatan dan Kepercayaan atas Teknologi Sistem Informasi terhadap kinerja Individual (Survey pada BPR di Kabupaten Karanganyar). Skripsi. Program Studi Akuntansi Fakultas Ekonomi dan Bisnis Universitas Muhammadyah Surakarta.

Bodnar, G. dan W. Hopwood. (2000). Sistem Informasi Akuntansi. Edisi Pertama. Jakarta: Salemba Empat.

Davis, F. D. dan V. Venkatesh. (2000). A Theoretical Extension of the Technology Acceptance Model: Four Longitudinal Field Studies. Management Science, 46(2). 
Dewantara, A. (2014). Pengaruh Efektivitas Penggunaan dan Kepercayaan Sistem Teknologi Informasi terhadap Kinerja Individual Pegawai pada PDAM Kota Surakarta. Skripsi. Universitas Muhammadiyah Surakarta.

Falgenti, K. dan S. M. Pahlevi. (2013). Evaluasi Kesuksesan Sistem Informasi ERP pada Usaha Kecil Menengah Studi Kasus: Implementasi SAP B1 di PT. CP. Jurnal Manajemen Teknologi Universitas Indraprasta PGRI, $12(2)$.

Jumaili, S. (2005). Kepercayaan terhadap Teknologi Sistem Informasi Baru dalam Evaluasi Kinerja Individual. Kumpulan Materi Simposium Nasional Akuntansi VIII, Solo, 15-16 September 2005.

Kasandra, N. M. A. A. (2014). Pengaruh Kualitas Penerapan Sistem Informasi Akuntansi, Pemanfaatan dan Kepercayaan Teknologi Informasi terhadap Kinerja Karyawan pada Bank Perkreditan Rakyat di Kabupaten Tabanan. E-Jurnal Akuntansi Universitas Udayana, 14(1).

Kelton, A. S., R. Robin., Pennington dan B. M. Tuttle. (2010). The Effect of Information Presentation Format on Judgement and Decision Making: A Review of the Information System Research. Journal of Information System, 24(2), 79-105.

Laudon., C. Kenneth., dan P. L. Jane. (2008). Sistem Informasi Manajemen: Mengelola Perusahaan Digital. Edisi 10. Jakarta: Salemba Empat.

Marlinawati, N. M. A. (2013). Pengaruh Penggunaan Teknologi Informasi, Efektifitas Sistem Informasi Akuntansi, Kepercayaan atas Sistem Informasi Akuntansi dan Kesesuaian Tugas pada Kinerja Karyawan Lembaga Perkreditan Desa Di Kabupaten Badung. E-Journal Akuntansi Universitas Udayana, 2(2).

McGill., Tanya., V. Hobbs dan J. Klobas. (2003). User-Developed Applications and Information Systems Success: a Test of DeLone and McLean's Model. Information Resource Management Journal, 16(1), 24.

Panggeso, N. F. (2014). Efektivitas Penggunaan dan Kepercayaan atas Sistem Informasi Akuntansi terhadap Kinerja Karyawan PT Bank Sulselbar di Makassar. Skripsi. Universitas Hasanuddin Makassar.

Pratama, G. A. P dan I. M. S. Suardikha. (2013). Keahlian Pemakai Komputer dan Kenyamanan Fisik dan Tingkat Efektivitas Sistem Informasi Akuntansi terhadap Kinerja Karyawan. E-Jurnal Akuntansi Universitas Udayana, 5(2), 361-381. 
Ni Luh Putu Dwi Gita Sari dan I Made Pande Dwiana Putra. Pengaruh...

Putra, A. M. (2016). Pengaruh Efektivitas Penggunaan, Kepercayaan, Keahlian Pengguna dan Kualitas Sistem Informasi Akuntansi terhadap Kinerja Karyawan pada PT PLN (PERSERO) Distribusi Bali. E-Jurnal Akuntansi Universitas Udayana, 17(2).

Rahmi, M. (2013). Pengaruh Penggunaan Teknologi Informasi dan Keahlian Pemakai terhadap Kualitas Informasi Akuntansi (Studi Empiris pada Perusahaan BUMN di Kota Padang). E-Jurnal Akuntansi Universitas Negeri Padang, 1(2).

Ratnaningsih, I. (2013). Pengaruh Kecanggihan Teknologi Informasi, Partisipasi Manajemen, Pengetahuan Partisipasi Manajemen, serta Pengetahuan Manajer Akuntansi terhadap Efektivitas Sistem Informasi Akuntansi pada Hotel Berbintang di Kabupaten Badung. E-Jurnal Akuntansi Universitas Udayana, 6(1).

Sari, dan M. M. Ratna. (2009). Pengaruh Efektivitas Penggunaan dan Kepercayaan terhadap Teknologi Akuntansi terhadap Kinerja Individual pada Pasar Swalayan di Kota Denpasar. Jurnal Ilmiah Akuntansi dan Bisnis Universitas Udayana, 4(1). 